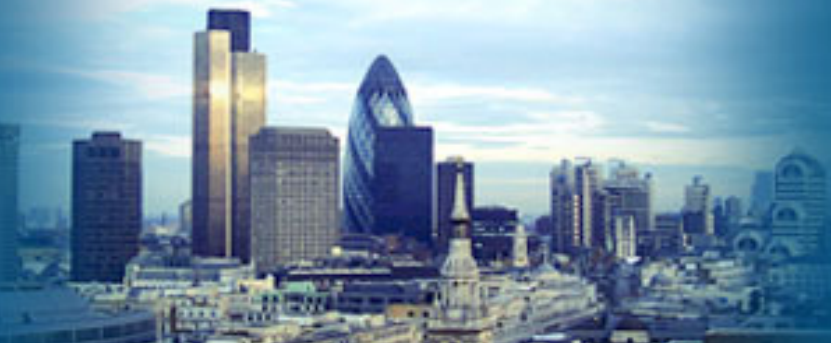

LONDON metropolitan university

CENTRE FOR EMEA BANKING, FINANCE \& ECONOMICS

\title{
Efficiency and Risk-taking in Pre-crisis Investment Banks
}

Nemanja Radić, Franco Fiordelisi, Claudia Girardone

Working Paper Series

No 08/11

Efficiency and risk-taking in pre-crisis investment banks 


\title{
Nemanja Radić ${ }^{1}$, Franco Fiordelisi ${ }^{2}$, Claudia Girardone ${ }^{3}$
}

\begin{abstract}
Investment banks' core functions expose them to a wide array of risks. This paper analyses cost and profit efficiency for a sample of investment banks for the G7 countries (Canada, France, Germany, Italy, Japan, UK and US) and Switzerland prior to the recent financial crisis. We follow Coelli et al. (1999)'s methodology to adjust the estimated cost and profit efficiency scores for environmental influences including key banks' risks, bank- and industry specific factors and macroeconomic conditions. Our evidence suggests that failing to account for environmental factors can considerably bias the efficiency scores for investment banks. Specifically, bank-risk taking factors (including liquidity and capital risk exposures) are found particularly important to accurately assess profit efficiency: i.e. profit efficiency estimates are consistently underestimated without accounting for bank risktaking. Interestingly, our evidence suggests that size matters for both cost and profit efficiency, however this does not imply that more concentrated markets are more efficient.
\end{abstract}

JEL classification: D2, G24, G32, L25

Key words: Investment Banking;Stochastic Frontier Analysis; Efficiency; Environmental Conditions; Banking Risks.

\footnotetext{
${ }^{1}$ Centre for EMEA Banking, Finance and Economics, London Metropolitan Business School, London Metropolitan University, 84 Moorgate, London EC2M 6SQ, UK; e-mail: n.radic@londonmet.ac.uk

²University of Rome III, Italy, Via S. D’Amico 77, 00145 Rome, Italy; e-mail: fiordeli@uniroma3.it

${ }^{3}$ University of Essex, Wivenhoe Park, Colchester, CO4 3SQ, UK; e-mail: cgirardone@essex.ac.uk
} 


\section{Introduction}

In the 'Great Moderation' era, the investment banking industry in all advanced economies benefited from the processes of liberalisation, internationalisation and consolidation activities. An increasing number of financial institutions have been involved in cross-border activities and in providing banking services globally. Investment banks' main business is to intermediate between issuers and investors through the functions of M\&A advisory services and underwriting of securities issues. They also provide trading and investing in securities and asset management.

Yet, investment banks' core function lays in the 'origination' of large and complex financial instruments that expose them to market risks and imply that their business relies predominantly on the short-term. The recent financial turmoil affected a relatively large number of investment banks. Under pressure for profits, these latter have contributed to the emergence of an unprecedented system of compensations, a highly leveraged industry and a pervasive risk culture. Post-crisis, surviving banks will have to comply with new constraints thus the evaluation of their operating efficiency will likely gain a new impetus, particularly on the cost side. In this context, the description of modern investment banks' production process should reflect the changes in their business focus. As well, it should account for risk and other environmental and regulatory factors.

The need for a correct evaluation of investment banks' efficiency can be explained by various reasons. First, investment banks typically have a large number of stakeholders since they engage in public and private market transactions for corporations, governments and investors. An inaccurate assessment of their operating efficiency could bias their performance analysis and, consequently, cover up their financial difficulties thus resulting in negative externalities for all investment banks' stakeholders (including governments, stake-issuers and, ultimately, investors). Second, the investment banking sector is probably one of the most globalised industries: investment banks from various countries compete with each other to acquire customers in all countries. As such, the assessment of investment banks' efficiency cannot accurately be made focussing on national banking market; rather it should take a worldwide perspective. Moreover, investment banking is a complex business mostly based on risk-taking and risk-transferring services. Therefore, a correct assessment and recognition of these risks play a key role in the investment banking efficiency estimation. Finally, investment banking is a revenue-motivated business. Managing the cost base has always been dominated by human capital, and influenced by investments in IT, global infrastructure and product platforms. However, this raises also the issue of the relationship between cost and revenues, which means that banks can match their cost base to the revenue generating potential over time. The most valuable of investment banks' tangible assets is staff, so that the largest expenses regard the workforce compensation and benefits. ${ }^{2}$ ${ }^{2}$ Other operating expenses are generally lower than compensation expenses, and concern communication and technology, occupancy and
depreciation, brokerage, clearing and exchanges fees, marketing and advertisements, office supplies, etc. For further details see e.g. Liaw (2006). 
The contribution of this paper to the existing literature is manifold. This study is one of the few focussing on the investment banking industry, which is surprisingly inadequately explored (e.g. Berger and Humphrey 1997, Berger 2007 and Hughes and Mester, 2008 do not cite any study on investment banks). Moreover, we assess both cost and profit efficiency of the investment banking industries operating in the G7 countries (Canada, France, Germany, Italy, Japan, UK and US) and Switzerland. Our goal is to carry out a suitable comparison of banking efficiency across countries by using a global best-practice econometric frontier whereby the banks in each country can be compared against the same standard. From a methodological point of view we employ Coelli et al. (1999)'s approach to adjust the estimated cost and profit efficiency scores for environmental influences. Specifically, we introduce a large set of environmental variables to account for potential differences arising from certain country-specific risk exposure on the one hand and from the environmental and regulatory conditions on the other. We choose to consider both cost and profit efficiency because investment banking is traditionally a revenue-motivated business and competitive pressure (e.g. due to deregulation and globalisation) put further pressure for the efficiency enhancement.

Our evidence suggests that failing to account for environmental factors can considerably bias the efficiency scores for investment banks. Specifically, our analysis indicates that profit efficiency estimates are consistently underestimated in the 'base model'. We find that investment banks with higher liquidity risk are penalised in the case of cost efficiency but have an advantage in generating profits and higher capital levels appear to increase the cost efficiency and reduce the profit efficiency. Interestingly, while our evidence suggests that size matters for both cost and profit efficiency, we find that this does not imply that more concentrated markets are more efficient. Finally, among the most significant results on the macro-factors, our findings imply that the general economic development of a country and the banks' level of openness contribute to reducing inefficiencies.

The next section reviews the bank efficiency literature with a particular focus on investment banks and on studies accounting for environmental variables in the efficiency measurement. Section 3 explains methodology and data. The empirical results are discussed in Section 4 and Section 5 concludes.

\section{Literature Review}

The efficiency studies applied to the banking sector focus predominantly on commercial banking (see e.g. the extensive reviews by Berger and Humphrey, 1997; Goddard et al. 2001; Berger, 2007; and Hughes and Mester, 2008). Only a handful of studies (Allen and Rai 1996, Vander Vennet 2002) analyse universal banking (which includes investment banking in their business) and compare it with traditional banking. Namely, Allen and Rai (1996) use the distribution-free approach (DFA) and stochastic frontier approach (SFA) for a systematic comparison of $\mathrm{X}$-inefficiency measures across 15 developed countries under different regulatory environments. Inputs selected to describe the production process of banks are the price of labour, the price of fixed capital and the price of 
borrowed funds, while outputs are defined as loans and investment assets. The authors estimate a global cost function for international banks to test for both input and output inefficiencies.

More recently, Vander Vennet (2002) uses the SFA in order to measure cost and profit efficiency of European financial conglomerates and universal banks over 1995-1996. The author employs an input specification similar to Allen and Rai's, whereas outputs are defined using two different approaches: one focussing on output volumes (i.e. total loans and total securities) and the other on output revenues (i.e. total interest income and total non-interest revenues). Results show that financial conglomerates are more revenue efficient than specialized banks and that universal banks are more efficient both on the cost and revenue side. The author suggests: 'Further research should examine the sources of the efficiency differences between various typs of banks' (Vander Vennet 2002, p. 280).

As far as we are aware, Beccalli (2004) is the only study directly examining the efficiency of investment firms by comparing the cost efficiency of UK and Italian investment firms over the period 1995-1998. Parametric stochastic frontier approach (SFA) is used in order to model cost efficiency. According to the author's findings, controlling for environmental variables is crucial in assessing the investment banking business since these factors have a significant influence on cost efficiency as well as profitability. In terms of cross-country operations, more efficient investment firms were found to be more international, thus exporting a more efficient model, while less efficient firms tend to attract foreign investment firms with higher efficiency.

The paucity of efficiency studies in investment banking can be explained by three main factors: first, the lack of good quality data; second, the difficulties in successfully modelling the peculiar nature of investment banks' production process (i.e. a problem of variables identification); and third, the need to accurately account for different environmental conditions in various countries: investment banking is a global business and efficiency needs to be measured running an international comparisons of investment banks.

Recent developments in the literature dealing with commercial banks can help to circumvent the latter two problems. Regarding the variables identification to successfully modelling the production process, this is a serious problem since the investment banking business is multifaceted. Gardener and Molyneux (1995) categorise the investment bank's business into five main areas: broking (i.e. the broking of securities is commodity business in which firms appeal to customers mainly on price and integrity); trading (i.e. the trading of securities drives on market volatility); core investment banking (i.e. the underwriting of new issues and advisory work also referred to as Mergers and Acquisitions); fund management (i.e. both retail and wholesale fund management); interest spread (i.e. income derivatives from borrowed funds). As such, the accurate measurement of the investment banking risktaking and risk-transferring is a key issue. Recent studies dealing with commercial banks included risk characteristics in cost or profit functions estimation, such as the liquidity risk exposure (Altunbas et al., 2000; Demirguc-Kunt and Huizinga, 2004; Brissimis et al., 2008; Fiordelisi and Molyneux, 2010); insolvency risk exposure (Lepetit et al., 2008); credit risk (Athanasoglou et al., 2008; Brissimis et al. 2008; Fiordelisi and Molyneux, 2010); capital risk exposure (Dietsch and Lozano-Vivas 2000, Lozano-Vivas et al. 2002, Altunbas et al. 2000, Athanasoglou 
et al. 2008, Brissimis et al. 2008, Lepetit et al. 2008); market risk exposure (Fiordelisi and Molyneux 2010); and the off-balance risk exposure (Casu and Girardone, 2005).

Regarding the need to assess investment banking efficiency on a worldwide base, there is an increasing number of studies dealing with commercial banks running international comparisons of bank efficiency by including environmental factors to face environmental differences across countries. By summarising 100 studies that compare bank efficiencies across different nations, Berger (2007) observes that efficiency has been measured using either: 1) the estimation of nation-specific frontiers; and 2) the estimation of common frontiers including specific variables in the estimation to account for countries differences. While the first approach guarantees the sample homogeneity, it does not enable the authors to directly compare banks from different countries. In contrast the second approach allows a direct comparison of efficiency levels and rankings from different countries (Coelli et al., 2005; Bos and Schmiedel, 2007) by implicitly assuming that banks in different countries have access to the same technology and effectively compete with each other. However, this approach requires dealing with the sample heterogeneity by controlling for systematic differences across banks that are not due to inefficiency ${ }^{3}$ : failure to account for heterogeneity is a likely candidate to cause instability of efficiency results as recently emphasised by Bos et al. (2009). Various studies focus on country-specific environmental factors in order to avoid this technology problem (see Lozano-Vivas et al., 2002; Dietsch and Lozano-Vivas, 2000).

Focussing on recent studies, various factors are used to account for countries' macro-economic differences, as the population density (Dietsch and Lozano-Vivas, 2000, Lozano-Vivas et al., 2002; Carbo-Valverde et al., 2007; Fiordelisi and Molyneux, 2010); the countries' wealth (e.g. the GDP procapita, as in Salas and Saurina, 2003; CarboValverde et al., 2007; Fitzpatrick and McQuinn, 2008; Brissimis et al., 2008; Fiordelisi and Molyneux, 2010); the density of demand and per capita income (Dietsch and Lozano-Vivas, 2000; Lozano-Vivas et al. 2002); the FDI inflows and outflows (Beccalli, 2004); the short-term interest rate, foreign and public ownership (Brissimis et al., 2008); inflation and cyclical output (Athanasoglou et al., 2008).

Overall, the vast majority of the literature on bank efficiency focuses on commercial banking and, to the best of our knowledge, only one study (Beccalli, 2004) has specifically investigated the investment firms' cost efficiency comparing UK and Italy. The present study advances the existing literature by examining specifically cost and profit efficiency of the investment banking industry in eight large industrialised countries and by taking into account of environmental factors in the estimation. The next section outlines the details of the methodology and data used. ${ }^{3}$ Deprins and Simar (1989), Kumbhakar and Lovell (2000) observe that it can be difficult to determine if an exogenous variable is a characteristic
of production technology or a determinant of productive efficiency. 


\section{Methodology}

\subsection{Stochastic frontier and environmental factors}

Our empirical analysis aims to identify the framework for comparing investment banks' efficiencies across nations. Cost and profit efficiency are measured using the Stochastic Frontier Analysis (SFA) that can be written as follows:

$$
\ln T C_{i, \mathrm{t}}=x_{\mathrm{i}, \mathrm{t}} \beta+\left(V_{\mathrm{i}, \mathrm{t}}+U_{\mathrm{i}, \mathrm{t}}\right)
$$

where $t$ denotes the time dimension, $\ln T C_{i}$ is the logarithm of the cost of production (pre-tax profits, PT, for the profit function) of the $\mathrm{i}$-th bank, $x_{i}$ is a $k x 1$ vector of input prices and output quantities of the $\mathrm{i}$-th bank, $\beta$ is a vector of unknown parameters, $V_{i}$ are random variables which are assumed to be i.i.d $\mathrm{N}\left(0, \sigma_{\mathrm{v}}^{2}\right)$ and independent of $U_{\mathrm{i}}$, $U_{\mathrm{i}}$ are non-negative random variables which are assumed to account for cost inefficiency and to be i.i.d. as truncations at zero of the $N\left(0, \sigma_{\cup}{ }^{2}\right)$. Following an approach similar to Altunbas et al. (2000), we use the following translog functional form ${ }^{4}$ :

$$
\begin{aligned}
& \ln T C_{k, t}(\ln T P)=\beta_{0}+\sum_{i=1}^{2} \beta_{i} \ln Y_{i}+\sum_{j=1}^{2} \alpha_{j} \ln P_{j}+\lambda_{\mathrm{l}} T+\frac{1}{2}\left(\sum_{\mathrm{i}=1}^{2} \sum_{\mathrm{j}=1}^{2} \delta_{\mathrm{ij}} \ln \mathrm{Y}_{\mathrm{i}} \ln \mathrm{Y}_{\mathrm{j}}+\sum_{\mathrm{i}=1}^{2} \sum_{\mathrm{j}=1}^{2} \gamma_{\mathrm{ij}} \ln \mathrm{P}_{\mathrm{i}} \ln \mathrm{P}_{\mathrm{j}}+\lambda_{11} \mathrm{~T}^{2}\right)+ \\
& +\sum_{\mathrm{i}=1}^{2} \sum_{\mathrm{j}=1}^{2} \rho_{\mathrm{ij}} \ln \mathrm{Y}_{\mathrm{i}} \ln \mathrm{P}_{\mathrm{i}}+\sum_{\mathrm{i}=1}^{2} \beta_{\mathrm{iT}} \mathrm{T} \ln \mathrm{Y}_{\mathrm{i}}+\sum_{\mathrm{j}=1}^{2} \alpha_{\mathrm{jT}} \mathrm{T} \ln \mathrm{P}_{\mathrm{j}}+\frac{1}{2} \tau_{\mathrm{EE}} \ln \mathrm{E} \ln \mathrm{E}+\tau_{\mathrm{E}} \ln \mathrm{E}+ \\
& \sum_{\mathrm{i}=1}^{2} \beta_{\mathrm{iE}} \ln \mathrm{Y}_{\mathrm{i}} \ln \mathrm{E}+\sum_{\mathrm{j}=1}^{2} \alpha_{\mathrm{jE}} \ln \mathrm{P}_{\mathrm{j}} \ln \mathrm{E}+\varepsilon_{\mathrm{kt}} \operatorname{Ext}_{k t} \ldots j v_{k t}+u_{k t}
\end{aligned}
$$

where $\ln T C_{\mathrm{kt}}(\mathrm{In} \mathrm{TP})$ is the natural logarithm of total cost (total profit) of bank $k$ in period $t, Y_{\mathrm{i}}$ is the vector of output quantities, $P_{\mathrm{j}}$ are the input prices, $E$ represents bank's equity capital and is included as a fixed input, specifying interaction terms with both output and input prices in line with recent studies (see e.g. Altunbas et al., 2000; Beccalli, 2004; and Vander Vennet, 2002). We include the time trend $t$ to capture technological change. ${ }^{5}$ We use this functional form to estimate a 'base model' for a common frontier of investment banks operating in the G7 countries and Switzerland (see Section 3.1 for more details). In this model, we do not account for possible heterogeneity in the sample. This problem is tackled in a second model that we estimate to account for heterogeneity including environmental conditions, or firm-specific factors, following the two methods proposed by Coelli et al. (1999) and that the authors define as 'Case I' and 'Case II' model (for a recent application, see e.g. Glass and McKillop, 2006).

\footnotetext{
${ }^{4}$ The choice of using the translog functional form is motivated by two main reasons. First, Altunbas and Chakravarty (2001) identify some problems associated with more flexible functional forms like the Fourier (Mitchell and Onvural, 1996) when dealing with heterogeneous data sets. Secondly, Berger and Mester (1997) observe that the translog and the Fourier-flexible are substantially equivalent from an economic viewpoint and both rank individual bank efficiency in almost the same order.

${ }^{5}$ As usual, symmetry and linear homogeneity restrictions are imposed standardising total cost $T C$ and input prices $P_{\mathrm{i}}$ by the last input price.
} 
In Case I, environmental factors are assumed to have a direct influence on the production structure. As such, we include some control variables in the deterministic portion of the stochastic frontier function in equation (2), as follows:

$$
\begin{aligned}
& \ln T C_{k, t}(\ln T P)= \beta_{0}+\sum_{i=1}^{2} \beta_{i} \ln Y_{i}+\sum_{j=1}^{2} \alpha_{j} \ln P_{j}+\lambda_{\mathrm{l}} T+\frac{1}{2}\left(\sum_{\mathrm{i}=1}^{2} \sum_{\mathrm{j}=1}^{2} \delta_{\mathrm{ij}} \ln \mathrm{Y}_{\mathrm{i}} \ln \mathrm{Y}_{\mathrm{j}}+\sum_{\mathrm{i}=1}^{2} \sum_{\mathrm{j}=1}^{2} \gamma_{\mathrm{ij}} \ln \mathrm{P}_{\mathrm{i}} \ln \mathrm{P}_{\mathrm{j}}+\lambda_{11} \mathrm{~T}^{2}\right)+ \\
&+\sum_{\mathrm{i}=1}^{2} \sum_{\mathrm{j}=1}^{2} \rho_{\mathrm{ij}} \ln \mathrm{Y}_{\mathrm{i}} \ln \mathrm{P}_{\mathrm{i}}+\sum_{\mathrm{i}=1}^{2} \beta_{\mathrm{iT}} \mathrm{T} \ln \mathrm{Y}_{\mathrm{i}}+\sum_{\mathrm{j}=1}^{2} \alpha_{\mathrm{jT}} \mathrm{T} \ln \mathrm{P}_{\mathrm{j}}+\frac{1}{2} \tau_{\mathrm{EE}} \ln \mathrm{E} \ln \mathrm{E}+\tau_{\mathrm{E}} \ln \mathrm{E}+ \\
& \sum_{\mathrm{i}=1}^{2} \beta_{\mathrm{iE}} \ln \mathrm{Y}_{\mathrm{i}} \ln \mathrm{E}+\sum_{\mathrm{j}=1}^{2} \alpha_{\mathrm{jE}} \ln \mathrm{P}_{\mathrm{j}} \ln \mathrm{E}+\sum_{\mathrm{j}=1}^{\mathrm{M}} \theta_{\mathrm{j}} \ln \mathrm{z}_{\mathrm{ji}}+\varepsilon_{\mathrm{kt}} \text { fori } \neq j \quad(3\}_{k t}=v_{k t}+u_{k t}
\end{aligned}
$$

where we account for $M$ environmental/firm specific factors, $z_{\mathrm{j}}$, assuming different values for each i-th firm.

In Case II, environmental/ firm-specific factors are assumed to influence the inefficiency distribution and are not directly included in the cost function. As noted by Battese and Coelli (1995), the stochastic frontier is estimated in the first stage under the assumption that the inefficiency effects (error term) are identically distributed, while in the second stage the predicted technical efficiencies are regressed upon a number of factors, hence suggesting the inefficiency effects are not identically distributed. A more suitable approach involves the specification of a model in which both relations are estimated in a single stage. This accounts for a stochastic frontier production function in which the technical inefficiency effects are a function of firm characteristics. ${ }^{6}$ The inefficiency components $u_{i}$ are assumed to be distributed independently, but not identically. For each i-th firm the technical inefficiency effect is obtained as truncation at zero of a normal distribution $N\left(\mu_{i}, \sigma^{2}\right)$ where the mean $\mu_{i}$ is a function of $M$ factors representing the firm-specific environment:

$$
m_{i t}=\delta_{0}+\sum_{j=1}^{M} \delta_{j} \ln z_{j i t}
$$

The deterministic portion of the frontier remains the same as in equation (3). In this case we are assuming that all firms share the same technology, and environmental/firm-specific factors have an influence only on the distance between each firm and the best-practice. The resulting efficiency estimates incorporate the effect of environmental factors and can be viewed as 'gross' measures of efficiency.

We apply the methods presented above also to estimate the alternative profit efficiency. The frontier definition is similar to the one described in equations (2) and (3). There are only two notable differences: we replace total cost (TC) with total profit (TP) as dependent variable; and the inefficiency term $\left(\mathrm{u}_{\mathrm{i}}\right)$ is subtracted (and not added as in the cost function), given that we need to solve a profit maximisation problem (rather than a cost minimisation). ${ }^{7}$

\footnotetext{
${ }^{6}$ For further readings see Coelli, et al. (1999, p. 255)

${ }^{7}$ Using a translog specification we have to solve the problem of sample banks with negative values of profit, for which we cannot take the logarithm. Therefore, the constant term $\theta=|\pi \mathrm{min}|+1$ is added to every firm's dependent variable in the profit function so that natural log is taken
} 
We choose to consider both cost and profit efficiency because investment banking is traditionally a revenuemotivated business and competitive pressure (e.g. due to deregulation and globalisation) put further pressure for the efficiency enhancement. Besides, as noted by Berger and Mester (1999, p. 3), 'profit maximization is superior to cost minimization for most purposes because it is the more accepted economic goal of firm's owners, who take revenues as well as costs into account when making decisions'.

\subsection{Data and variables}

This study comprises banks' balance sheet, income statement and annual reports data for the G7 countries (Canada, France, Germany, Italy, Japan, UK and US) and Switzerland over 2001-2007 ${ }^{8}$. The data were compiled from the International Bank Credit Analysis Bankscope Database. Table 1 illustrates the breakdown by country of the number and asset size of the banks included in the sample. The total number of observations is 800 ; the US banks are the biggest on average by asset size, whereas Switzerland has the largest number of institutions both as a total and by year. ${ }^{9}$

Table 1. Sample description: number of banks and average asset size by country

\begin{tabular}{|cccccccccc|}
\hline Country/Year & 2001 & 2002 & 2003 & 2004 & 2005 & 2006 & 2007 & Total by country & $\begin{array}{c}\text { Total assets of the } \\
\text { average bank* }\end{array}$ \\
\hline Canada & 1 & 1 & 1 & 2 & 3 & 4 & 4 & 16 & $3,951,175$ \\
France & 2 & 2 & 2 & 3 & 5 & 9 & 7 & 30 & $26,175,525$ \\
Germany & 6 & 8 & 6 & 8 & 8 & 11 & 8 & 55 & $12,182,958$ \\
Italy & 2 & 1 & 2 & 3 & 5 & 6 & 6 & 25 & $1,814,332$ \\
Japan & 2 & 6 & 19 & 23 & 23 & 22 & 19 & 114 & $29,686,104$ \\
UK & 9 & 9 & 10 & 20 & 27 & 32 & 25 & 132 & $36,565,124$ \\
USA & 15 & 19 & 21 & 18 & 15 & 14 & 9 & 111 & $115,358,872$ \\
Switzerland & 50 & 44 & 44 & 45 & 45 & 45 & 44 & 317 & $21,406,169$ \\
\hline Total by year & 87 & 90 & 105 & 122 & 131 & 143 & 122 & 800 & \\
\hline
\end{tabular}

* All values are in thousand dollars.

In the bank efficiency literature, the definition of inputs and outputs varies across studies and mainly depends on the researcher's assumptions on the production process of banks. For multi-product commercial banks, much of

for a positive number (Berger and Mester, 1997). Thus, for the firm with the lowest value for that year, the dependent variable will be $\ln (1)=0$. However our analysis has shown that by using this measure, for dealing with losses, we obtain biased data. Based on that, and since the number of banks exhibiting a loss is small relative to the sample size (less than $10 \%$ of the sample), we choose to drop relative observations as in Humphrey and Pulley (1997). Similar adjustments have been used by e.g. Vander Vennet (2002); Casu and Girardone (2004); Fiordelisi (2007); Fitzpatrick and McQuinn (2008).

${ }^{8}$ The investigation of the financial crisis' effects on investment banks' efficiency would require a different research methodology and a tailored dataset (therefore we do not include 2008 data in the sample). In addition, the number of banks available in Bankscope for 2008 would be drastically reduced making our sample heterogeneous.

${ }^{9} \mathrm{We}$ are aware that Bankscope data on investment banks is not as detailed as for commercial banks. One of the main limitations is that the input and output data cannot be disaggregated by investment banking function or activity (e.g. merger and acquisition advisory). 
the debate is on how to treat deposits: the 'intermediation approach' assumes that they are inputs to the banks' production process while the 'production approach' views them as outputs. The most common of these two approaches is probably the former, where inputs are identified as labour, physical capital and deposits. On the other hand, there seems to be some agreement on what constitutes output, i.e. the dollar volume of banks' assets and, more frequently, total loans and other earning assets (Hughes and Mester, 2008; Goddard et al. 2001; Berger and Humphrey, 1997).

Since investment banks' main business is not lending, it would be inaccurate to borrow the input/output definition used for commercial banks to describe the production process of investment banks. As discussed in Section 2, the extant literature on investment bank efficiency is rather limited. Beccalli (2004) employs the price of labour and price of physical capital as inputs, while debtors plus bank deposits is the single output.

In this study, we assume that in carrying out their production process investment banks use two 'standard' input variables: labour and physical capital. Specifically the price of labour $\left(P_{1}\right)$ is calculated as personnel expenses over total assets; and the price of physical capital $\left(P_{2}\right)$ is measured as other administrative expenses plus other operating expenses over total fixed assets. On the output side, we choose a novel definition to capture investment banks' main business as follows: total earning assets $\left(Y_{1}\right)^{10}$, that is the sum of loans and other earning assets ${ }^{11}$; and investment banking fees $\left(\mathrm{Y}_{2}\right)$, calculated as the sum of commission, fee and trading income. As in Altunbas et al., (2001), we include both stock and flow variables as outputs. The main motivation stems from the particular nature of the investment banking business as derived from their financial statements, and on the assumptions we make on the investment banks' production process. ${ }^{12,}$

In order to estimate cost and profit efficiency scores, we use as dependent variablestotal cost (TC), calculated as the sum of personnel expenses, other administrative expenses and other operating expenses; and total pre-tax profit $(T P)$. The variable equity $(E)$ controls for the differences in equity capital across banks. Table 2 reports the descriptive statistics of the inputs and outputs used in the empirical analysis.

\footnotetext{
${ }^{10}$ As a robustness test, we also re-estimate all models with the total interest income added in the definition of investment banks' total earning assets. The new efficiency estimates are very similar to the original estimates thereby suggesting that our main findings are robust across different output specifications. We thank the referee for suggesting this test.

${ }^{11}$ Following the Bankscope 'global' specification, the item 'other earning assets'comprises deposits with banks, due from central banks, due from other banks, due from other credit institutions, total securities, treasury bills, other bills, bonds, CDs, equity investments andother investments.

${ }^{12}$ However, in this study we have carried out various robustness tests by using alternative models. First, the number of input and output specifications for our model has been tested. We have estimated alternative models with total funds both as inputs and outputs, and interest income as additional output. The chosen specification seems to best fit the available data.
} 
Table 2. Descriptive statistics of inputs and outputs*

\begin{tabular}{clccccc}
\hline Variable & Description & Mean & Median & Std. Dev. & Min. & Max \\
\hline TC & Total Cost & $1,325,752$ & 149,368 & $4,622,540$ & 76 & $70,302,088$ \\
TP & Pre-Tax Profits & 308,618 & 37,321 & $1,004,517$ & 60 & $10,815,637$ \\
$Y_{1}$ & Total Earning Assets & $32,527,530$ & $1,359,342$ & $101,254,934$ & 6,931 & $972,522,434$ \\
$Y_{2}$ & Investment Banking Fees & 660,916 & 112,575 & $1,916,440$ & 52 & $21,082,186$ \\
$P_{1}$ & Price of Labour & 0.049 & 0.028 & 0.079 & 0.0001 & 1.093 \\
$P_{2}$ & Price of Physical Capital & 20.491 & 2.871 & 98.088 & 0.143 & 1862.00 \\
E & Total Equity & $1,673,869$ & 249,585 & $4,624,642$ & 371 & $49,180,809$ \\
\hline
\end{tabular}

* All values are in thousand dollars, except for relative prices.

In order to account for heterogeneity we follow Coelli et al. (1999)'s approach that proposes two different ways of including environmental conditions or firm-specific factors in the cost/profit function: Case I, where environmental factors have a direct influence on the production structure; and Case II, where environmental factors influence the inefficiency distribution.

In order to decide on which firm-specific factors to account for to tackle the heterogeneity problem in our sample, we follow the most recent empirical literature in this area. Accordingly, we account for potential differences arising from country-specific aspects of banking technology on one hand and from the environmental and regulatory conditions on the other. In particular, the economic environment is likely to differ significantly across countries. Three categories of environmental variables are taken into account: (1) variables that describe the structure of the banking industry and risks; (2) those that describe the main macroeconomic conditions, which determine the banking product demand characteristics; and (3) those that account for bank profitability.

The first group of environmental factors, named 'banking structure and risks', consists of four specific risk variables (capital risk, liquidity risk, securities risk, insolvency risk) and six bank and market specific variables: asset diversification, bank asset size, Herfindahl index of concentration, income diversification, Off-Balance Sheet business and publicly listed banks. A detailed list with related literature can be found in Table 3 . 
Table 3. Environmental variables included in the estimation and related literature

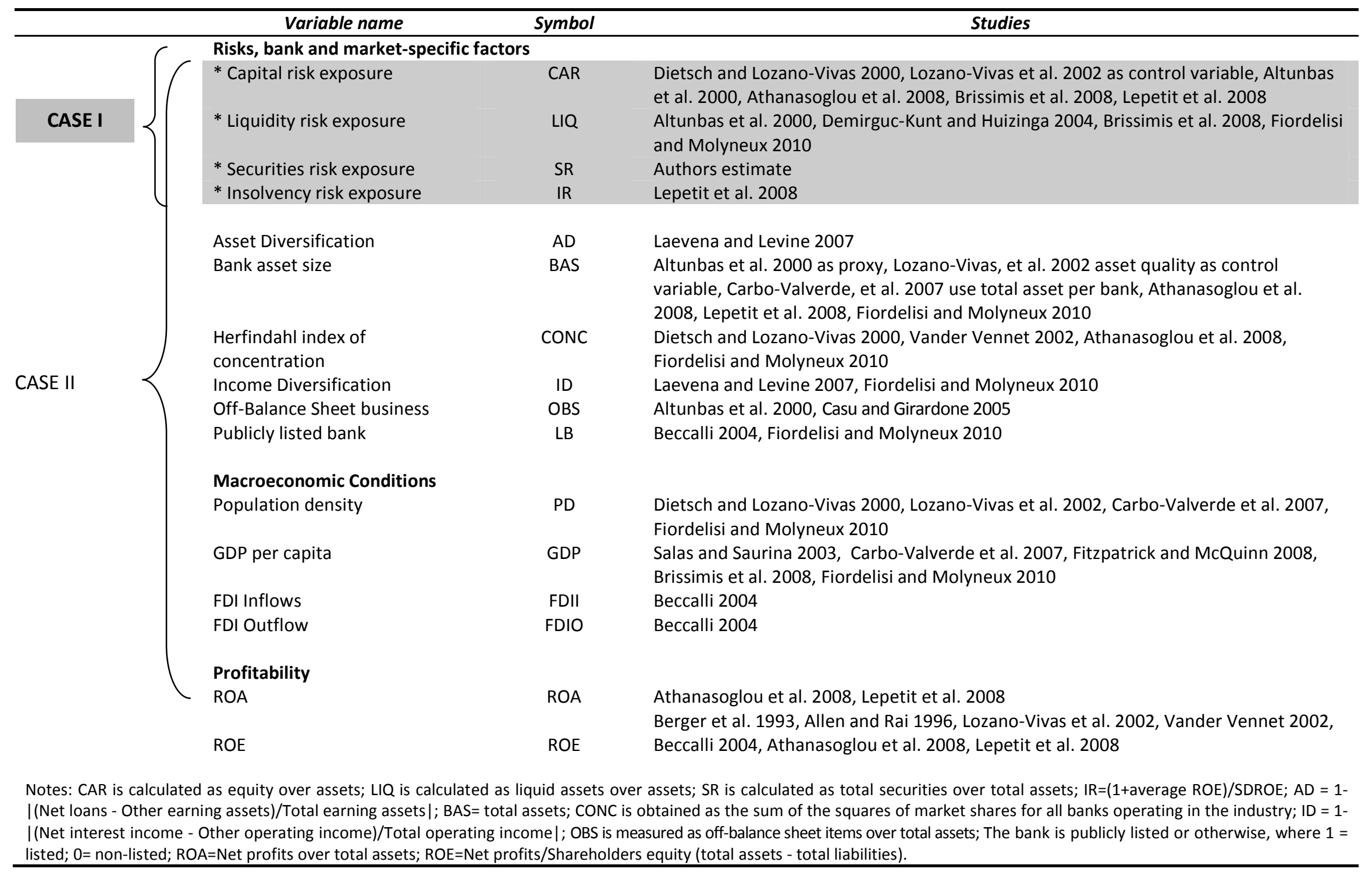


Many efficiency studies outlined the importance of accounting for bank risk preferences (see for example Mester, 1997; Altunbas et al. 2000; Lepetit et al. 2008). In our study we use five measures of risk, based on annual accounting data and determined for each bank throughout the period. Capital risk exposure represents a proxy for regulatory conditions, and we measure it as equity over total assets. Usually, a lower capital ratio leads to lower efficiency levels because less equity implies higher risk taken at greater leverage, which normally results in greater borrowing costs.

Low level of liquidity is one of the major causes of bank failures. During periods of increased uncertainty, financial institutions may decide to diversify their portfolios and/or raise their liquid holdings in order to reduce their risk. Banks would therefore improve their efficiency by improving screening and monitoring of liquidity risk, and such policies involve the forecasting of future levels of risk. Following the empirical literature, we use the ratio of liquid to total assets (LIQ) to proxy liquidity risk.

Given the nature of the investment banking business and specifically their securities issuance and underwriting, has led us to introduce one more risk variable. We call it securities risk exposure, and define it as total securities over total assets.

We also compute insolvency risk measures which proxies the probability of failure of a given bank based on its ' $\mathrm{Z}$ score' as in Lepetit et al. (2008) as follows:

$$
\text { Z-score }=(100+\text { average ROE }) / \sigma R O E
$$

Higher values of Z-scores imply lower probabilities of failure. Moreover, we add asset diversity (AD) as a measure of diversification across different types of assets. AD is calculated as:

$$
A D=1-\mid \text { (Net loans }- \text { Other earning assets) / Total earning assets } \mid
$$

Other earning assets include securities and investments, and total earning assets is the sum of net loans and other earning assets. Asset diversity takes values between 0 and 1 with higher values indicating greater diversification (see, for more details, Laeven and Levine, 2007).

One of the most important questions underlying bank policy is which size optimizes bank efficiency. Generally, the effect of a growing size on efficiency has been proved to be positive to a certain extent. However, for banks that become extremely large, the effect of size could be negative due to bureaucratic and other reasons. Even if there are no clear conclusions and results change depending on the methodologies applied (as outlined in Weill, 2004) accounting for size differences is certainly significant. Another important environmental variable is banking industry concentration that is measured by the Herfindahl-Hirshmann index. This is defined as the sum of squared 
asset market shares of all banks in each country. Higher concentration may be associated with either higher or lower costs.

To take into account of the diversification across different sources of income, we include a measure of income diversity that is calculated as:

$$
I D=1-\mid \text { (Net interest income - Other operating income) / Total operating income } \mid
$$

Income diversity takes values between zero and one with higher values indicating greater diversification. The asset and income diversity measures are complementary in that asset diversity is based on stock variables and income diversity is based on flow variables.

We also account for the level of off-balance sheet (OBS) items over assets and assume that they generate additional (and 'hidden') financial exposures for banks. Although OBS business has originally developed to help banks prepare for contingencies, recent events have shown that often this type of business produces additional risks for the parties involved in these types of contract.

The publicly listed bank is not just a pure scale measure, but represents the opportunity for diversification offered by the market to the clients of investment firms. Our sample includes both listed and unlisted banks. Beccalli et al. (2006) showed the existence of a positive relationship between efficiency and stock performance. Therefore our hypothesis is that listed banks could be more efficient since they are more exposed to competitive pressures.

The second group of environmental variables is defined 'macroeconomic conditions' and includes a measure of population density, GDP per capita, inflows and outflows of foreign direct investment (FDI). These indicators describe the main conditions under which banks operate. The supply of banking services in areas with a low population density generates higher banking costs, and does not encourage banks to increase their efficiency levels. GDP per capita affects numerous factors related to the demand and supply of banking services. Countries with a higher GDP per capita have a banking system that operates in a mature environment resulting in more competitive interest rates and profit margins. Finally, FDI is a measure of foreign ownership of productive assets. Cross-border mergers and acquisitions in the developed world as well as direct and portfolio investment in emerging markets have fuelled the profitability of these sectors, primarily US-based banks, which have had the relationship and networks to capture these flows. We expect to find, a positive (negative) relationship with cost (profit) efficiency.

The third and last category of environmental variables is bank-specific profitability determinants, measured by the return on assets (ROA) and the return on equity (ROE). In principle, ROA reflects the ability of a bank's management to generate profits from the bank's assets, although it may be biased due to OBS activities. ROE indicates the return to shareholders on their equity.

Previous research focussing on cross-country comparison of bank efficiency measure (Dietsch and Lozano-Vivas, 2000; Beccalli, 2004; Fiordelisi and Molyneux, 2006), has pointed out the importance of country-specific 
characteristics. In line with the main literature, we choose to include country dummies $\left(C D_{k}\right)$ to control for different national conditions. ${ }^{13}$

\section{Empirical results}

In our empirical analysis we assess the efficiency of investment banks. In order to account for sample heterogeneity, three models are estimated: 1) the base model, i.e. a common frontier that includes only the structural variables described in equation (2); b) the Case I model, where environmental conditions/firm- specific factors have a direct influence on the production process (equation 3); and 3) Case II, where environmental factors influence the inefficiency distribution, i.e. the Battese and Coelli's (1995) model (equation 4). In the first case, our estimates provide a 'net' measure of efficiency, i.e. the managerial efficiency. In the second case, our estimates provide us with a 'gross' measure of efficiency since firm-specific (i.e. measured as mean at the national industry level) and macro-economic factors are considered as determinants of inefficiency effects to account for country differences. $^{14}$

Chart 1 displays the estimated mean cost and profit efficiency levels as calculated in the three alternative models. In line with the (predominantly commercial) bank efficiency literature (see Berger and Mester, 1997 for a review, Maudos et al., 2002), the mean cost efficiency scores are on average higher than the profit ones in all models. Moreover, estimated efficiency scores also suggest marked differences in efficiency across the countries included in our sample (see Table A1 in the Appendix).

\section{Chart 1. Cost and profit efficiency estimates (means)}

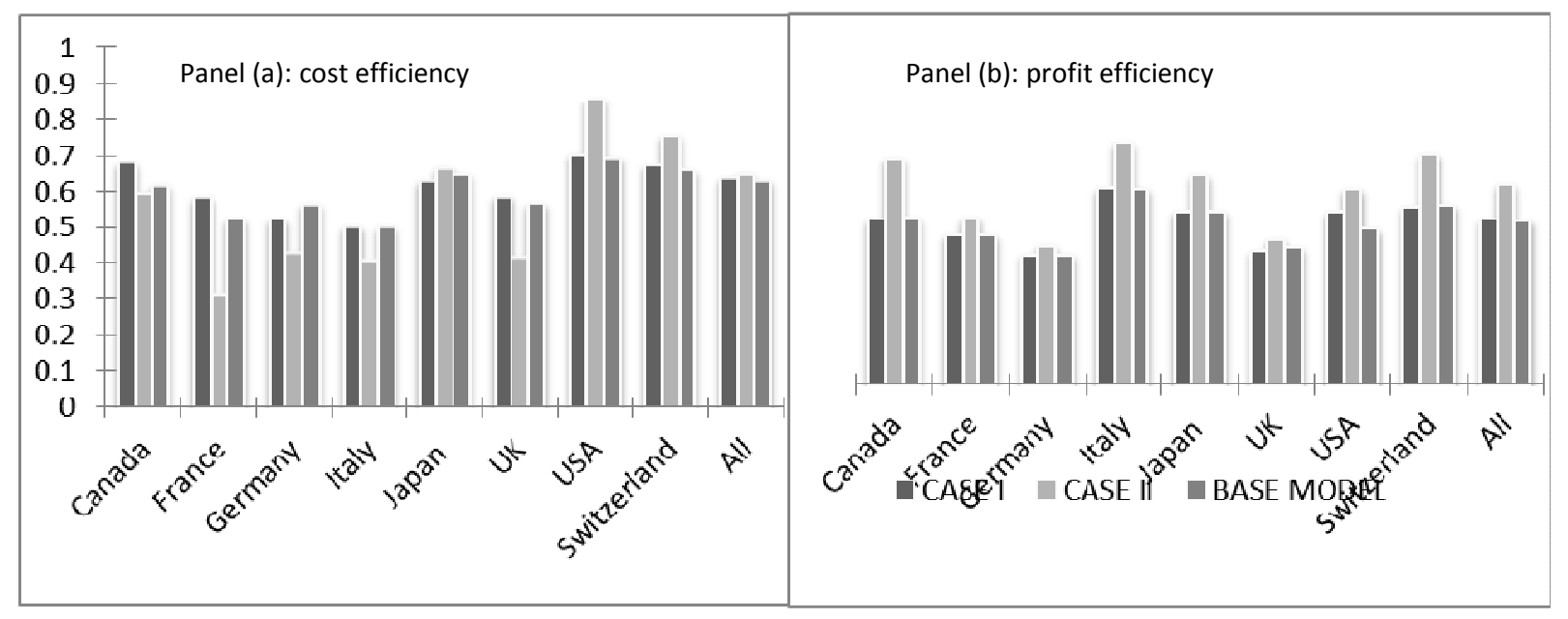

\footnotetext{
${ }^{13}$ As usual one dummy (Canada) is dropped from the model to avoid multicollinearity. So we have a total of seven country dummies.

${ }^{14}$ Only the combination of structural characteristics and environmental ones allows us to capture the industry efficiency and explain national differences.
} 
Results show that, on average, the efficiency scores estimated using the base model are generally similar to those derived from Case I for both cost (panel a) and profit (panel b). In contrast, Case II shows substantial differences in average values for all countries for both cost and profit efficiency. Furthermore on the profit side, it seems clear that average efficiency scores are consistently underestimated in the base model ${ }^{15}$. Our results are consistent with Coelli et al. (1999) who found that Case I efficiency estimates are generally lower than those obtained under Case II and these differences are mostly explained by the way in which the environment variables are included in these models. We also agree with Coelli et al. (1999) in preferring the Case II estimates for two reasons: first, these estimates represent the outer boundary of the production possibility set; and second, gross efficiency measures obtained from Case II are the closest to the intuitive notion of efficiency being about converting physical inputs into physical outputs.

Regarding Case I, we focus on bank risk-taking variables (omitting to consider macro-economic variables) by including these in the deterministic portion of the stochastic frontier function. We posit that bank risk-taking variables have a direct impact on bank cost and profit efficiency, while macro-economic variables and industrylevel features only impact on the distribution of the inefficiency components, but not on the efficiency of a single bank (i.e. these variables influence in the same manner the efficiency to all banks in the same nation). We found all risk variables significant at $1 \%$ level in the cost case, while on the profit side we found statistically significant (at the $10 \%$ confidence level or less) the coefficients for liquidity and securities risk exposure (Table 4). Since these variables are measured at the bank level, coefficient estimates can be directly interpreted to measure the relationship between these factors with cost and profit efficiency estimates.

Specifically, coefficient estimates are negative (and high) for the capital risk and security risk exposures, while are positive for the liquidity risk and insolvency risk exposures. In the profit function estimation, coefficients for liquidity and securities risk are found to be statistically significant (the first is positive and the second is negative), while the other two risk exposure measures are insignificant. These results provide evidence that capital and securities risk have a positive effect on the cost efficiency while the relationship with liquidity and insolvency risk exposures is negative. The liquidity risk has also a positive effect on profit efficiency while the securities risk has a negative impact.

The interpretation of these results is particularly interesting considering the investment bank crisis that began in 2007: our results show that, by including bank risk-taking factors to assess the efficiency in the pre-crisis period, investment banks with a higher liquidity are penalized in the case of cost efficiency, but have an advantage in generating profits, while the opposite is found for the securities risk exposure (i.e. more securities holding, more cost and less profit efficiency). As such, highly capitalized banks incur lower costs to provide banking services

\footnotetext{
${ }^{15}$ Statistically testing which model would best fit the data is not straightforward. As suggested by the relevant literature (see for example Coelli et al. 1999), one would need to create an artificial nested model. Due to data constraints and to different set of environmental variables used in the two models, we can only decide on the basis of theoretical motivations.
} 
probably by developing more careful management systems and internal auditing processing. However, highly capitalized banks cannot exploit the leverage effect and this negatively impact on profitability. On the other hand, if a bank's capital level decreases, managers have an increasing incentive to take on excessive risk, engaging in activities that fail to create value for shareholders. ${ }^{16}$ During periods of increased uncertainty, financial institutions may decide to diversify their portfolios and/or raise their liquid holdings in order to reduce their risk: this would have a negative impact on bank cost efficiency, but will result in higher profits (less risk, less opportunity cost of capital).

Table 4. Environmental factors affecting the shape of the cost and profit functions (Case I)

\begin{tabular}{c|lll}
\hline Variable & Description & $\begin{array}{l}\text { Inefficiency effect } \\
\text { (Cost) }\end{array}$ & $\begin{array}{l}\text { Inefficiency effect } \\
\text { (Profit) }\end{array}$ \\
\hline Z1 (CAR) & Capital risk & $-1.1357^{* * *}$ & -0.1547 \\
Z2 (LIQ) & Liquidity risk & $0.0542^{* * *}$ & $0.0808^{* * *}$ \\
Z3 (SR) & Securities risk & $-0.0823^{* * *}$ & $-0.0884^{* * *}$ \\
Z4 (IR) & Insolvency risk & $0.0652^{* * *}$ & -0.0122 \\
\hline
\end{tabular}

$*, * *, * * *$ means statistically significant at the $10 \%, 5 \%$ and $.1 \%$ respectively.

Note: $C A R=$ calculated as equity over assets; $L I Q=$ liquid assets over assets; $S R$ = total securities over total assets; $\mathrm{IR}=(1+$ average $\mathrm{ROE}) / \mathrm{SDROE}$.

Turning to the results on Case II (Table 5), environmental variables are measured at the industry level so coefficient estimates can be interpreted as a measure of the relationship between the national industry features (e.g. the mean level of capital risk exposure in the country considered) and cost and profit efficiency estimates: this analysis provides particularly useful insight for economic policy-makers and regulators. The influence of the environmental variables on the inefficiency is in line with our expectations and a number of variables have been found statistically significant at the $10 \%$ confidence level or less.

Regarding the four risk variables tested in Case I, estimated coefficients for capital and liquidity risk exposures are negative and positive (statistically significant at the $1 \%$ confidence levels) in cost and profit inefficiency estimates, respectively. These results provide evidence that the mean industry level of capital ratio and the liquidity risk exposures have a positive impact on cost efficiency (by reducing the mean of the cost inefficiency component), while have a negative influence to profit efficiency (by increasing the mean of the profit inefficiency component). Capital risk exposure results in both Case I and II are strongly consistent with each other confirming that higher

\footnotetext{
${ }^{16}$ These results are similar with Casu and Girardone (2004).
} 
capital level increase the cost efficiency (e.g. enhancing internal auditing systems and managers motivation) and reduce the profit efficiency (e.g. reducing the financial leverage effect). Our results for bank liquidity risk exposure are slightly different: banks working in countries with a higher level of liquidity have a positive impact on cost efficiency, while have a negative impact in profit efficiency. A possible explanation is that banks operating in more liquid banking systems find it cheaper to manage liquidity so that these benefit from lower costs. However, cost of funds and credit spreads will be probably low and this would negatively impact on bank lending by reducing profits.

Concerning the remaining environmental factors, Table 5 shows that in the majority of cases the chosen variables are highly significant. This gives a preliminary (although rather crude) indication that failing to account of these additional factors can potentially bias the estimated efficiency scores. 
Table 5. Environmental / Firm-specific factors determining the inefficiency distribution (Case II)

\begin{tabular}{|c|c|c|c|}
\hline Variable & Description & $\begin{array}{l}\text { Inefficiency effect } \\
\text { (Cost) }\end{array}$ & $\begin{array}{l}\text { Inefficiency effect } \\
\text { (Profit) }\end{array}$ \\
\hline \multicolumn{4}{|c|}{ Risks, bank and market-specific factors } \\
\hline $\mathrm{Z1}$ (CAR) & Capital risk & $-1.1209 * * *$ & $5.1352 * *$ \\
\hline $\mathrm{Z2}$ (LIQ) & Liquidity risk & $-1.2875^{* * *}$ & $12.0503 * * *$ \\
\hline $\mathrm{Z3}(\mathrm{SR})$ & Securities risk & 0.1234 & 0.1456 \\
\hline $\mathrm{Z4}(\mathrm{IR})$ & Insolvency risk & 0.1101 & $-0.6277^{*}$ \\
\hline $\mathrm{Z5}(\mathrm{AD})$ & Asset diversification & -0.6730 & $-3.1355^{* * *}$ \\
\hline Z6 (BAS) & Bank asset size & $-0.1355^{* *}$ & $-0.4820 * *$ \\
\hline $\mathrm{Z7}(\mathrm{CONC})$ & Concentration & $0.5905 * * *$ & $1.4813^{* * *}$ \\
\hline $\mathrm{Z8}$ (ID) & Income diversification & 0.0535 & $8.5812^{* * *}$ \\
\hline Z9 (OBS) & OBS business & -0.0928 & $-0.5467 * * *$ \\
\hline $\mathrm{Z10}(\mathrm{LB})$ & Listed banks & $-1.2976 * * *$ & $-3.9457 * * *$ \\
\hline \multicolumn{4}{|c|}{ Macroeconomic Conditions } \\
\hline $\mathrm{Z11}(\mathrm{PD})$ & Population density & $0.3283 * *$ & -0.4003 \\
\hline $\mathrm{Z12}$ (GDP) & GDP per capita & $-0.8065^{* * *}$ & $1.9647^{* * *}$ \\
\hline Z13 (FDII) & FDIs inflows & $-0.1929 * * *$ & 0.5770 \\
\hline Z14 (FDIO) & FDI outflows & 0.0879 & $-1.5560 * * *$ \\
\hline \multicolumn{4}{|c|}{ Profitability } \\
\hline Z15 (ROA) & Return on Assets & $2.6002 * *$ & $-39.7617^{*}$ \\
\hline Z16 (ROE) & Return on Equity & $-0.1681^{*}$ & -0.5750 \\
\hline \multicolumn{4}{|c|}{ Country dummies } \\
\hline $\mathrm{Z} 17$ & France Dummy & $1.6615^{* * *}$ & -0.7228 \\
\hline Z18 & Germany Dummy & $1.4109 * * *$ & 0.8338 \\
\hline Z19 & Italy Dummy & 0.5187 & $-9.5681 * * *$ \\
\hline $\mathrm{Z} 20$ & Japan Dummy & 0.3711 & -0.6215 \\
\hline $\mathrm{Z21}$ & Switzerland Dummy & $-2.0076 * * *$ & $-8.6367 * * *$ \\
\hline $\mathrm{ZZ2}$ & UK Dummy & $1.8746^{* * *}$ & $7.2744^{* * *}$ \\
\hline $\mathrm{ZZ23}$ & US Dummy & $-6.5516 * * *$ & $20.7140 * * *$ \\
\hline
\end{tabular}

$*, * *, * * *$ means statistically significant at the $10 \%, 5 \%$ and $.1 \%$ respectively.

Note: $C A R=$ calculated as equity over assets; LIQ =liquid assets over assets; $S R=$ total securities over total assets; IR=(1+average ROE)/SDROE; $A D=1-\mid$ (Net loans - Other earning assets)/Total earning assets $\mid ; B A S=$ total assets; CONC =sum of the squares of market shares for all banks; $I D=1-\mid$ (Net interest income - Other operating income)/Total operating income |; OBS =off-balance sheet items over total assets; The bank is publicly listed or otherwise, where $1=$ listed; $0=$ non-listed; ROA=Net profits over total assets; ROE=Net profits/Shareholders equity (total assets - total liabilities).

Focusing on the cost side (column 1 in Table 5), the magnitude of the coefficients is particularly high for the dummy of listed banks (LB) and the profitability ratio (ROA). Indeed, listed companies seem to have a negative relationship with both cost and profit inefficiency, thus providing strong evidence that on average banks that are quoted in stock markets tend to be less inefficient. ${ }^{17}$ On the other hand, our findings for ROA suggest that the most profitable banks are less cost and more profit efficient.

${ }^{17}$ On the relationship between efficiency and stock performance see e.g. Beccalli et al. (2006). 
Turning to the inefficiency effect in profits (column 2 in Table 5), asset and income diversification (AD and ID respectively) seem to be remarkably high and significant. Nevertheless, they are both insignificant on the cost side and they seem to have an opposite effect on profit efficiency. This is likely due to the higher volatility of income streams, and the possibility that more diversified banks may have been affected by trading losses over the studied period. However, banks doing more OBS business seem to be more profit efficient on average.

Special attention should be paid to bank asset size (BAS) and market concentration (CONC): our evidence implies that size matters for both cost and profit efficiency; however, this is not necessarily reflected in more efficient concentrated markets. ${ }^{18}$ These findings have some interesting implications. First of all because they give further support to the assumption that efficiency and performance are amongst the main motives for bank mergers and acquisitions, and secondly, because they indicate that on average more concentrated markets are less likely to be cost and profit efficient. ${ }^{19}$

Lastly, the macroeconomic variables included in the models (PD, GDP and FDI) seem to affect the inefficiency levels in various ways. Focusing on the most significant and larger coefficients, it seems that investment banks operating in more developed economies (with higher GDP per capita) present higher profit and lower cost inefficiencies. Finally, the sign and magnitude of the coefficient estimate for FDI outflows suggests that the most efficient investment banks are more likely to operate abroad (for similar findings see e.g. Beccalli, 2004).

\subsection{Robustness Checks}

In order to further confirm the aforementioned findings, a number of robustness checks were conducted by testing alternative models. Firstly, we investigate the impact that banks' size has on efficiency: as shown in Table 5, investment banks' size is found to be an important efficiency determinant. To further confirm this conclusion, we consider two sub-samples of the largest and smallest banks, i.e. the fourth and first quartile of the size distribution as reported in Table 6.

\footnotetext{
${ }^{18}$ To further confirm these results, we carried out several robustness tests. Specifically, we carried out a t-test to the two subsamples of the largest and smallest banks in the sample (i.e. the fourth and first quartile of the size distribution). Results are robust only for the cost case where smaller investment banks are more efficient then larger banks at $10 \%$ significance level.

${ }^{19}$ Actually these findings could even be signaling some evidence of the validity of Hick's quiet life hypothesis in investment banking and thus should be explored in more detail (Hicks, 1935).
} 
Table 6. Small versus big investment banks ${ }^{a}$

\begin{tabular}{c|ccccc}
\hline Case II Model & $\begin{array}{c}\text { Small (Mean) } \\
200 \text { Obs }\end{array}$ & $\begin{array}{c}\text { Big (Mean) } \\
200 \text { Obs }\end{array}$ & Mean Diff. & $t$-Stat & $p$-Value \\
\hline Cost & 0.6861 & 0.6216 & 0.0644 & 2.6133 & $0.0093^{* * *}$ \\
Profit & 0.5522 & 0.5120 & 0.0401 & 1.6450 & 0.1008 \\
\hline
\end{tabular}

Notes: Small: smallest investment banks, Big: biggest investment banks (fourth and first quartile of the size distribution).

*** indicates significance at $10 \%$ level

${ }^{a}$ Two sample t-test of differences in mean between Small and Big, under the assumption of unequal variance. HO: mean(Small)-mean(Big) $=0 \quad H 1$ : mean(Small)-mean(Big) $\neq 0$

Table 6 shows that for the cost case, smaller investment banks are more efficient than larger banks, at the $10 \%$ significance level.

Secondly, we create a cluster sample by investment bank type to provide some additional analysis of the obtained efficiency results for the investment banking industry. The aim is to distinguish between boutique investment banks (BIB) and full service investment banks (FSIB). ${ }^{20}$ Despite the obvious differences in relative size across these alternative types of financial institutions, we expect them to be driven by fairly different strategic objectives. Namely, we assume that while boutique investment banks specialize in particular segments of the market in order to achieve greater profitability and survive competitive pressure from their larger peers in the industry, full service investment banks strive to control their cost base in order for to maximize their share of revenue. Table 7 shows the breakdown by country in terms of number of FSIBs and BIBs.

Table 7. Full services investment banks (FSIB) and Boutique Investment Banks (BIB) by country

\begin{tabular}{l|ccc}
\hline Country & $\begin{array}{c}\text { \# of } \\
\text { FSIB }\end{array}$ & $\begin{array}{c}\text { \# of } \\
\text { BIB }\end{array}$ & Total \\
\hline & 2 & & \\
Canada & 4 & 2 & 4 \\
France & 7 & 9 & 9 \\
Germany & 3 & 7 & 16 \\
Italy & 11 & 15 & 10 \\
Japan & 24 & 35 & 26 \\
Switzerland & 25 & 15 & 59 \\
UK & 19 & 7 & 40 \\
USA & & & 26 \\
Total & $\mathbf{9 5}$ & $\mathbf{9 5}$ & 190 \\
\hline
\end{tabular}

\footnotetext{
${ }^{20}$ FSIBs offer clients a range of services including underwriting, merger and acquisition advisory services, trading, merchant banking and prime brokerage. BIBs specialize in particular segments of the market. Typically they do not offer a broad range of services and are not part of larger financial institutions. For more details see Davis (2003), andGardener and Molyneux (1995).
} 
As illustrated in Table 8, in the cost case FSIBs are significantly more efficient than boutique investment banks, while the results are opposite in terms of profit efficiency.

Table 8. Full service investment banks vs boutique investment banks: robustness test ${ }^{a}$

\begin{tabular}{c|ccccc}
\hline $\begin{array}{c}\text { Case II } \\
\text { Model }\end{array}$ & $\begin{array}{c}\text { FSIB Mean } \\
\text { (415 Obs) }\end{array}$ & $\begin{array}{l}\text { BIB Mean } \\
\text { (385 Obs) }\end{array}$ & Mean Diff. & T-Stat & P-Value \\
\hline Cost & 0.6727 & 0.6231 & 0.0495 & -2.8431 & $0.0046^{* * *}$ \\
Profit & 0.5047 & 0.5949 & -0.0902 & 5.6493 & $0.0000^{* * *}$ \\
\hline
\end{tabular}

Notes: ${ }^{* * *}$ indicates significance at $10 \%$ level

${ }^{a}$ Two sample $t$-test of differences in mean between FSIB and BIB, under the assumption of unequal variance. $H O:$ mean $(F S I B)-$ mean $(B I B)=0 \quad H 1$ : mean $(F S I B)-$ mean $(B I B) \neq 0$

These results can be explained by the better cost management and stronger base (in terms of different operational areas) within these institutions. In the profit efficiency case we find that BIBs display higher efficiency scores, therefore confirming the theoretical premises ${ }^{21}$, where ensuring high and persistent profitability is only way for them to remain competitive and survive inside highly concentrated markets.

Thirdly, our sample comprises from a relatively high proportion of Swiss investment banks (317 observations out of 800 ), and accordingly we run another robustness test to verify whether these banks would have driven the main results. Namely, we dropped Swiss banks from the sample and re-estimated both cost and profit efficiency. As shown in Table 9, new efficiency estimates are very similar with those discussed in the result section ${ }^{22}$ so we can conclude that our main results are not driven by the inclusion of Swiss bank in the sample.

\footnotetext{
${ }^{21}$ For more readings see Liaw (2006); and Gardener and Molyneux (1995).

${ }^{22} \mathrm{We}$ assess the similarity between the two set of efficiency estimates using both the Spearman's rho correlation and Pearson correlation coefficients (for all models). All estimated coefficients are constantly greater than $90 \%$.
} 
Table 9. Cost and profit efficiency scores by model and by country (excluding Switzerland)

\begin{tabular}{l|ccc}
\hline Country & Base & Case I & Case II \\
\hline Cost Efficiency & & & \\
Canada (16) & 0.6198 & 0.6509 & 0.6041 \\
France (30) & 0.5432 & 0.5544 & 0.3982 \\
Germany (55) & 0.5863 & 0.5296 & 0.4724 \\
Italy (25) & 0.5328 & 0.5279 & 0.3483 \\
Japan (114) & 0.6374 & 0.6102 & 0.6794 \\
UK (132) & 0.5729 & 0.5745 & 0.3859 \\
USA (111) & 0.6564 & 0.6510 & 0.8479 \\
Switzerland (317) & $/$ & $/$ & $/$ \\
Mean & 0.6065 & 0.5942 & 0.5772 \\
& & & \\
Profit Efficiency & & & 0.6527 \\
Canada (16) & 0.4670 & 0.4895 & 0.4839 \\
France (30) & 0.4057 & 0.4203 & 0.3870 \\
Germany (55) & 0.3636 & 0.3617 & 0.6825 \\
Italy (25) & 0.5464 & 0.5235 & 0.5870 \\
Japan (114) & 0.4669 & 0.4775 & 0.4256 \\
UK (132) & 0.3854 & 0.3681 & 0.5818 \\
USA (111) & 0.4337 & 0.4874 & $/$ \\
Switzerland (317) & $/$ & $/$ & 0.5196 \\
Mean & 0.4256 & 0.4359 & \\
\hline
\end{tabular}

\section{Conclusions}

The recent financial turmoil has uncovered a number of weaknesses of the banking industry and has left the international community with challenging questions about the evolving role of (commercial and investment) banks in the economy and the primary objective of ensuring financial stability. Over the last two decades investment banks' operations, functions and strategies have been increasingly market-driven and have contributed to the emergence of an unprecedented system of compensations, a highly leveraged industry and a pervasive risk culture. It is expected that post-crisis investment banks will have to comply with new constraints thus the evaluation of their operating efficiency will likely gain a new impetus, particularly on the cost side. In this context, the description of modern investment banks' production process should reflect the changes in their business focus. As well, it should account for risk and other environmental and regulatory factors.

This paper investigates the operating efficiency of the investment banking sector over 2001-2007 for the G7 countries (Canada, France, Germany, Italy, Japan, UK and US) and Switzerland. We follow Coelli et al. (1999)'s methodology to adjust the estimated cost and profit efficiency scores for environmental influences including key 
banks' risks, bank- and industry specific factors and macroeconomic conditions. Specifically we estimate three models: a base model, i.e. a common frontier that ignores environmental variables; Case I model, where environmental conditions/ firm-specific factors have a direct influence on the production process; and Case II model, where environmental factors influence the inefficiency distribution.

Overall, our evidence suggests that not accounting for environmental factors can considerably bias the efficiency scores of investment banks. Specifically, our analysis indicates that profit efficiency estimates are consistently underestimated in the base model. Moreover, in comparing the results between Case I and Case II, we observe that the difference in average efficiency levels is around $1 \%$ on the cost side, while on the profit side the results diverge by almost 10 percentage points. The vast majority of the tested environmental factors in the two models were found statistically significant: for example we find strong evidence that by including bank risk-taking factors to assess the efficiency in a pre-crisis period, investment banks with a higher liquidity are penalized in the case of cost efficiency, but have an advantage in generating profits.

Turning to bank and industry-specific factors, results are mixed on the relationship between inefficiencies, asset size and market concentration. While our evidence implies that size matters for both cost and profit efficiency, we find that this does not imply that more concentrated markets are more efficient. Finally, among the most significant results on the macro-factors, are that the general economic development of a country and the banks' level of openness contribute to reducing inefficiencies. 


\section{References}

Allen, L., Rai, A., 1996. “Operational efficiency in banking. An international comparison. “Journal of Banking and Finance, 20, 655-672.

Altunbas, Y., Chakravarty, S.P., 2001. “Frontier cost functions and bank efficiency”. Economics Letters, 72, 233-240.

Altunbas, Y., Gardener, E.P.M., Molyneux, P., Moore, B., 2001. “Efficiency in European banking”. European Economic Review 45, $1931-1955$.

Altunbas, Y., Liu, M.H., Molyneux, P., Seth, R., 2000. “Efficiency and risk in Japanese banking”. Journal of Banking and Finance, 24, $1605-1628$.

Athanasoglou, P.P., Brissimis, S.N., Delis, M.D., 2008. "Bank-specific, industry-specific and macroeconomic determinants of bank profitability”. Int. Fin. Markets, Inst. and Money, 18, 121-136.

Battese, G.E., Coelli, T.J., 1995. "A model for technical inefficiency effects in stochastic frontier production function. for panel data".Empirical Economics, Vol. 20, pp.325-332.

Beccalli, E., 2004. "Cross-country comparisons of efficiency: evidence from the UK and Italian investment firms" Journal of Banking and Finance, 28 1363-1383.

Beccalli, E., Casu, B., Girardone, C., 2006. "Efficiency and stock performance in European banking". Journal of Business Finance and Accounting, Vol. 33, No. 1-2, 245-262

Berger, A.N., 2007. "International comparisons of banking efficiency". Financial Markets, Institutions \& Instruments, Vol. 16, No. 3, 119-144.

Berger, A.N. Humphrey, D.B., 1997. "Efficiency of financial institutions: international survey and directions for further research". European Journal of Operational Research, 98, 175-212.

Berger, A.N., Mester, L.J., 1997. “Inside the black box: what explains differences in the efficiencies of financial institutions?”. Journal of Banking and Finance, 21, 895-947.

Berger, A.N., Mester, L.J., 1999. "What explains the dramatic changes in cost and profit performance of the U.S. banking industry?”. Working paper, 99-10, The Wharton School, University of Pennsylvania.

Berger, A.N., Hancock, D., Humphrey, D.B., 1993. "Bank efficiency derived from the profit function”. Journal of Banking and Finance, Vol. 17, 317-347.

Bos, J.W.B., Schmiedel, H., 2007. “Is there a single frontier in a single European banking market?” Journal of Banking and Finance, 31, $2081-2102$.

Bos, J.W.B., Koetter, M., Kolari, J.W., Kool, C.J.M., 2009. "Effects of heterogeneity on bank efficiency scores”. European Journal of Operational Research, 195, 251-261.

Brissimis, S.N., Delis, M.D., Papanikolaou, N.I., 2008. "Exploring the nexus between banking sector reform and performance". Journal of Banking and Finance, 32, 2674-2683.

Carbo-Valverde, S., Humphrey, D.B., Lopez del Paso, R., 2007. "Do cross-country differences in bank efficiency support a policy of "national champions?" Journal of Banking and Finance, 31, 2173-2188.

Casu, B., Girardone, C., 2005. "An analysis of the relevance of OBS Items in explaining productivity change in European banking" Applied Financial Economics, 15, 1053-1061.

Casu, B., Girardone, C., 2004. "Financial conglomerates: strategic drive and impact on bank efficiency and productivity". Applied Financial Economics, 14, 687-696.

Coelli, T., Perelman, S., Romano, E., 1999. “Accounting for environmental influences in stochastic frontier models: with application to international airlines". Journal of Productivity Analysis, 11, 251-273.

Coelli, T.J., Rao, D.S.P., O'Donnell, C., Battese, G.E., 2005. An introduction to efficiency and productivity analysis. Springer, $2^{\text {nd }}$ Edition.

Davis, S.I., (2003). Investment banking: Addressing the management issues. Palgrave MacMillan

Demirguc-Kunt, A., Huizinga, H., 2004. “Market discipline and deposit insurance”. Journal of Monetary Economics, 51, 375-399.

Deprins, D., Simar, L., 1989. "Estimating technical inefficiencies with correction for environmental conditions: with an application to railway companies". Annals of Public and Cooperative Economics, vol. 60(1), 81-102.

Dietsch, M., Lozano-Vivas A., 2000. "How the environment determines banking efficiency: a comparison between French and Spanish industries" Journal of Banking and Finance, 24, 985-1004.

Fiordelisi, F., 2007. "Shareholder value efficiency in European banking” Journal of Banking and Finance, 31, 2151-2171. 
Fiordelisi, F., Molyneux, P., 2010. “The determinants of shareholder value in European banking” Journal of Banking and Finance, 34, 1189-1200.

Fiordelisi, F., Molyneux, P., 2006. Shareholder Value in Banking. Palgrave Macmillan.

Fitzpatrick, T., McQuinn, K., 2008. “Measuring bank profit efficiency”. Applied Financial Economics, vol. 18(1), 1-8.

Gardener, E.P.M., Molyneux P., 1995. "Investment banking: theory and practice”. Euromoney Books.

Glass, J.C., McKillop, D.G., 2006. “The impact of differing operating environments on US Credit Union Performance, 1993-2001”. Applied Financial Economics, 16, 1285-1300.

Goddard, J., Molyneux, P., Wilson, J.O.S., 2001. European banking: efficiency, technology and growth. Wiley Finance.

Hicks, J., 1935. "The theory of monopoly". Econometrica, 3, 1-20.

Hughes, J.P., Mester, L.J., 2008. "Efficiency in banking: theory, practice and evidence". Working paper, 08-1, The Wharton School, University of Pennsylvania.

Humphrey, D.B., Pulley, L.B., 1997. "Banks' responses to deregulation: profits, technology, and efficiency”. Journal of Money, Credit and Banking, Volume 29, Issue 1, pp. 73-93.

Kumbhakar, S.C., Lovell C.A.K., 2000. Stochastic frontier analysis. Cambridge University Press.

Laeven, L., Levine, R., 2007. “Is there a diversification discount in financial conglomerates?”Journal of Financial Economics, 85, 331-367.

Lepetit, L., Nys, E., Rous, P., Tarazi, A., 2008. Bank income structure and risk - An empirical analysis of European banks. Journal of Banking and Finance, $32,1452-1467$.

Liaw, K.T., 2006. "The business of investment banking. A comprehensive overview" John Wiley \& Sons, $2^{\text {nd }}$ Edition.

Lozano-Vivas, A., Pastor, J.T., Pastor, J.M., 2002. “An efficiency comparison of European banking systems operating under different environmental conditions". Journal of Productivity Analysis, 18, 59-77.

Maudos, J., Pastor, J.M., Perez, F., 2002. "Competition and efficiency in the Spanish banking sector - the importance of specialization". Applied Financial Economics, 12, 505-516.

Mester, LJ., 1997. “Measuring efficiency at U.S. banks: accounting for heterogeneity is important. "European Journal of Operational Research, 98, 230-242.

Mitchell, K., Onvural N.M., 1996. "Economies of scale and scope at large commercial banks: evidence from the Fourier-flexible functional form. Journal of Money, Credit, and Banking, 28, 178-199.

Salas, V., Saurina, J., 2003. “Deregulation, market power and risk behavior in Spanish banks”. European Economic Review, 47, 1061 - 1075.

Vander Vennet, R., 2002. “Cost and profit efficiency of financial conglomerates and universal banks in Europe”. Journal of Money, Credit and Banking, Vol. 34, No. 1, 254-282.

Weill L., 2007. “Is there a gap in bank efficiency between CEE and Western European countries?” Comparative Economic Studies, 49, $101-127$. 


\section{Appendix}

Table A1. Cost and profit efficiency scores by model and by country

\begin{tabular}{l|ccc}
\hline Country & Base Model & Case I & Case II \\
\hline Cost Efficiency & & & \\
& & & \\
Canada (16) & 0.6183 & 0.6801 & 0.5965 \\
France (30) & 0.5245 & 0.5844 & 0.3131 \\
Germany (55) & 0.5658 & 0.5235 & 0.4307 \\
Italy (25) & 0.5021 & 0.5030 & 0.4062 \\
Japan (114) & 0.6494 & 0.6291 & 0.6665 \\
UK (132) & 0.5682 & 0.5877 & 0.4167 \\
USA (111) & 0.6956 & 0.7056 & 0.8602 \\
Switzerland (317) & 0.6588 & 0.6726 & 0.7565 \\
& & & \\
Profit Efficiency & & & \\
Canada (16) & & & 0.6205 \\
France (30) & 0.4559 & 0.4527 & 0.4559 \\
Germany (55) & 0.4089 & 0.4087 & 0.3809 \\
Italy (25) & 0.3537 & 0.3548 & 0.6624 \\
Japan (114) & 0.5362 & 0.5367 & 0.5728 \\
UK (132) & 0.4742 & 0.4744 & 0.3972 \\
USA (111) & 0.3750 & 0.3650 & 0.5345 \\
Switzerland (317) & 0.4241 & 0.4716 & 0.6319 \\
\hline
\end{tabular}

